\title{
PENGARUH PENERAPAN GOOD CORPORATE GOVERNANCE TERHADAP KINERJA KEUANGAN PERBANKAN YANG TERDAFTAR DI BURSA EFEK INDONESIA
}

\author{
Delfalina, Aminar Sutra Dewi \\ Sekolah Tinggi Ilmu Ekonomi KBP \\ delfalina92@gmail.com
}

\begin{abstract}
This study aims to determine the effect of Good Corporate Governance on the board of commissioners, boards of directors, and institutional ownership of the financial performance of the company. The sample used is the financial sector company in 20011-2015 amounted to 30 samples. The type of data used is secondary data obtained from www.idx.co.id. The hypothesis in this study was tested using multiple linear regression. The result of hypothesis testing shows that the board of commissioner has positive and not significant influence, the board of directors has positive and not significant impact to the company's financial performance (ROE). institutional ownership has a positive and significant impact on ROE.
\end{abstract}

Keywords: Board of Commissioners, Board of Directors, Institutional ownership, and ROE.

\section{PENDAHULUAN}

Di Indonesia, perlu dilakukan pengawasan terhadap perusahaan pada sektor keuangan. Hal ini dimaksudkan agar Indonesia memiliki system keuangan yang sehat secara fundamental dan berkesinambungan. Pengawasan pada sector keua ngan ini perlu diawasi juga untuk dapat melindungi kepentingan konsumen dan mayarakat. Dengan kata kinerja keuangan perusahaan disebut juga suatu Dewasa ini, dunia usaha semakin dinamis. Perkembangan kemampuan usaha menjadi suatu hal yang sangat penting agar dapat bertahan di pasar glabal. Sehingga tidak heran bahwa kini perusahaan berlomba-lomba meningkatkan daya saingnyadi berbagai bidang. Salah satu upaya perusahaan dalam meningkatkan kualitas perusahaan adalah dengan penerapan tata kelola perusahaan yang baik. Dengan tata kelola perusahaan yang baik, perusahaan diharapkan dapat meningkatkan kinerja perusahaan serta profitabilitas perusahaan.

Kinerja merupakan gambaran dari pencapaian pelaksaan suatu kegiatan dalam mewujudkan tujuan perusahaan. Dimana salah satu tujuan penting didirikannya perusahaan adalah memaksimalkan kekayaan pemegang saham melalui peningkatan nilai perusahaan (Brigham dan Houston, 2001). Menurut Dwiermayanti (2009) "kinerja keuangan perusahaan adalah suatu gambaran 
tentang kondisi keuangan suatu perusahaan yang dianalisis dengan alat-alat analisis keuangan, sehingga dapat diketahui mengenai baik buruknya keadaan keuangan suatu perusahaan yang mencerminkan prestasi kinerja dalam periode tertentu".

Kinerja keuangan perusahaan merupakan prestasi kerja yang telah dicapai oleh perusahaan dalam suatu periode tertentu dan tertuang dalam laporan keuangan perusahaan yang bersangkutan. Dalam penelitian kinerja perusahaan selalu menggunakan laporan keuangan. Laporan keuangan merupakan suatu informasi yang menggambarkan kondisi keuangan perusahaan dan informasi tersebut dapat dijadikan sebagai gambaran kinerja keuangan perusahaan. Menurut Lembaga Administrasi Negara (2003:3)

\section{LANDASAN TEORI}

\section{Kinerja Keuangan}

Pengerian kinerja keuangan adalah penentuan ukuran-ukuran tertentu yang dapat mengukur keberhasilan suatu perusahaan dalam menghasilkan laba. Secara umum laporan keuangan sering digunakan sebagai ukuran penilaian kinerja keuangan perusahaan. Laporan keuangan tercermin dari informasi yang diperoleh pada laporan laba rugi, neraca, dan laporan arus kas. Laporan keuangan diperlukan karena bisa memberikan informasi yang menjadi input untuk pengambilan keputusan (Hanafi \& Halim, 2009).

Kinerja keuangan dapat diukur dengan menganalisa dan mengevaluasi laporan keuangan. Penilaian kinerja bank menjadi sangat penting dilakukan karena posisi perbankan yang vital di dalam stabilitas perekonomian nasional. Perbankan memainkan peran penting dalam mobilisasi dana, alokasi, kedit, system pembayaran, dan implementasi kebijakan moneter (Mohammed dan Fatimoh, 2012).

Salah satu rasio untuk menghitung kinerja perusahaan adalah return on equity (ROE). Return on Equity menunjukan kemampuan perusahaan dalam menghasilkan laba setelah pajak dengan memanfaatkan total equity (modal sendiri) yang dimiliki.

$$
R O E=\frac{\text { Laba bersih setelah pajak }}{\text { Total Ekuitas }} \times 100 \%
$$

\section{Dewan Komisaris}

Dewan komisaris merupakan salah satu fungsi control yang terdapat dalam suatu perusahaan. Fungsi control yang dilakukan oleh dewan komisaris merupakan salah satu bentuk praktis dari teory agensi. Di dalam suatu perusahaan, dewan komisaris mewakili mekanisme internal utama untuk melaksanakan fungsi pengawasan dari principal dan mengontrol perilaku oportunis manajemen. Dewan komisaris menjembatani kepentingan principal dan manajer di dalam perusahaan.

Dewan Komisaris adalah fungsi dari perusahaan yang berperan melakukan supervise terhadap dewan direksi (Forum for corporate governance in Indonesia, 2000). Variabel penelitian ini dengan mengukur banyaknya ukuran dewan komisaris.

\section{Dewan Direksi}

Dewan direksi yaitu dewan yang dipilih oleh pemegang saham, bertugas mengawasi pekerjaan yang dilakukan manejemen dalam mengelola perusahaan, 
dengan tujuan kepentingan para pemegang saham. Ukuran dewan direksi dalam perusahaan sangatlah penting untuk pencapaian komunikasi yang efektif antara anggota dewan. Komunikasi yang baik akan meningkatkan pengawasan terhadap manajemen dalam perusahaan sehingga dpat mengurangi perilaku oportunis manajemen.

\section{Kepemilikan Institusional}

Kepemillikan Institusional adalah jumlah persentase hak suara yang dimiliki oleh institusi (Beiner et.al, 2003). Menurut Helen Short, Hao Zhang dan Kevin Keasey (2002), mendefinisikan kepemilikan institusional sebagai Kepemilikan yang dimiliki oleh lembaga yang memiliki persentase dan ekuitas sebesar $5 \%$ atau lebih dari modal awal pada tahun yang bersangkutan.

Kepemilikan institusional adalah jumlah kepemilikan saham oleh pihak investor institusional dari berbagai bidang perusahaan dan lembaga keuangan. Pada perusahaan public di Indonesia, mayoritas institusional ownership diperoleh dari jumlah persentase hak suara yang dimiliki oleh institusional ownership (S. Beiner et al. 2003). Variabel ini diukur berdasarkan indicator jumlah saham yang dimiliki institusi dari seluruh modal saham yang beredar. Pengukurannya menggunakan skala rasio.

\section{Dewan Komisaris dan ROE}

Dewan komisaris ditugaskan dan diberi tanggung jawab atas pengawasan kualitas informasi yang terkandung dalam laporan keuangan. Hal ini penting mengingat adanya kepentingan dari manajemen untuk melakukan manajemen laba yang berdampak pada berkurangnya kepercayaan invertor. Untuk mengatasinya dewan komisaris diperbolehkan memiliki otoritas dalam perusahaan, maka dewan direksi bertanggung jawab menyampaikan informasi terkait dengan perusahaan kepada dewan komisaris (NCCG, 2001).

Dengan tingkat pengawasan yang baik maka akan berpengaruh terhadap kinerja perusahaan, karena manajemen akan bertindak sesuai dengan yang diharapkan oleh stakeholder dan dihapkan dapat meningkatkat efektivitas dan efisiensi perusahaan. Berdasarkan uraian tersebut hipotesis penelitian berikutnya yang dikemukakan adlah sebagai berikut:

H1 : ukuran dewan komisaris berpengaruh positif terhadap kinerja keuangan perusahaan.

\section{Dewan Direksi dan ROE}

Dewan direksi merupakan salah satu indicator vital dalam pelaksanaan corporate governance yang bertanggung jawab dalam manajemen perusahaan. Dean direksi diharapkan dapat meningkatkan kinerja keuangan yang lebih baik. Dewan direksi memiliki tugas uantuk menentukan arah kewajiban dan strategi sumber daya yang dimiliki perusahaan, baik untuk jangka pendek maupun jangka panjang. Dalam undang-undang perseroan terbatas, disebutkan bahwa dewan direksi memiliki hak untuk mewakili perusahaan dalam urusan di luar maupun di dalam peruahaan.

Oleh karena itu proporsi dewan (baik dewan direksi maupun dewan komisaris) berperan dalam kinerja perusahaan dan dapat meminimalisasi kemungkinan terjadinya permasalahanagensi dalam perusahaan. Pfeffer \& Salancik juga menjelaskan bahwa semakin besar kebutuhan akan hubungan 
ekternalyang semakin efektif, maka kebutuhan akan dewan dalam jumlah yang besar akan semakin tinggi. Berdasarkan uraian tersebut hipotesis untuk penelitian ini adalah:

$\mathrm{H} 2 \quad$ : ukuran dewan direksi berpengaruh positif terhadap kinerja keuangan perusahaan.

\section{Kepemilikan Institusional dan ROE}

Kepemilikan institusional merupakan kepemilikan saham oleh pihak institusi lain yaitu kepemilikan oleh perusahaan atau lembaga lain. Kepemilikan sahamoleh pihak-pihak yang terbentuk institusi seperti perusahaan asuransi, bank, perusahaan investasi, dan kepemilikan institusi lain. Kepemilikan institusional merupakan satu alat yang dapat digunakan untuk mengurangi agency conflict. Kepemilikan institusional memiliki kemampuan untuk mengendalikan pihak mamajemen melalui proses monitoring secara efektif.

Penelitian yang dilakukan oleh Porter (1992), Midiastuty dan Mas'ud mahfoedz (2003) mengatakan bahwa kepemilikan institusional berpengaruh positif terhadap kinerja perusahaan. Berdasarkan uraian di atas hipotesis untuk penelitian selanjutnya adalah:

H3 : kepemilikan institusioanal berpengaruh positif terhadap kinerja keuangan perusahaan.

\section{METODE PENELITIAN}

Populasi dalam penelitian ini adalah seluruh perusahaan perbankan konvensional yang listed di Bursa Efek Indonesia dan berstatus masih aktif. Jumlah sampel yang digunkan adalah 30 sampel.

\section{Analisis Stasistik Deskriptif}

Uji statistic deskriptif berkenaan dengan bagaimna data dapat digambarkan/dideskripsikan, baik secara numeric misalnya menghitung rata-rata, standar deviasi atau secara grafik dalam bentuk table atau grafik. Untuk mendapatkan gambaran umum tentang data yang telah diperoleh.

\section{Uji Stasioneritas}

Stasioner merupakan suatu kondisi data time series yang jika rata-rata, varian dan covarian dari perubahan tersebut seluruhnya tidak dipengaruhi oleh waktu (Junaidi, 2013). Model pengujian stasioneritas dan aker unit yang akan digunakan disini adalah metode Augmented Dickey Fuller (ADF) dan Philips Perron (PP).

\section{Uji Normalitas Data}

Uji normalitas adalah uji untuk melihat apakah distribusi data mengikuti pola distribusi normal atau tidak, atau menguji apakah dalam sebuah model regresi, variable dependen, variable independen, atau keduanya mempunyai distribusi normal atau tidak.

\section{Uji Multikolinearitas}

Uji Multikolinearitas yaitu uji hubungan sesama variabel bebas .Multikolinearitas adalah keadaan dimana variabel-variabel independen dalam persamaan regresi mempunyai korelasi (hubungan) yang erat satu sama lain. 


\section{Uji Autokorelasi}

digunakan untuk melihat ada tidaknya autokorelasi, autokorelasi adalah korelasi yang terjadi diantara anggota-anggota dari serangkaian pengamatan yang tersusun dalam data time series. Apabila terjadi autokorelasi didalam suatu model, artinya varian sampel tidak menggambarkan varian populasinya.

\section{Uji Heteroskedastisitas}

Uji Heteroskedastisitas dilakukan dengan uji Glejser untuk mengetahui apakah data tersebar secara merata atau tidak yang kita inginkan tidak terjadi heteroskedastisitas atau sebaran data merata dan tidak membentuk suatu pola tertentu.

\section{Analisis Regresi Linear Berganda}

Hal ini dilakukan untuk menentukan ketepatan prediksi apakah ada pengaruh antara variabel dependen dengan variabel independen. Penelitian ini menggunakan program Eviews untuk memperoleh semua nilai yang diinginkan pada model analisis regresi dan pengujian secara statistik.

\section{Uji f}

Uji F digunakan untuk menguji pengaruh variabel bebas secara bersamasama atau simultan terhadap variabel terikat.

\section{Uji t}

Digunakan untuk menguji pengaruh variabel independen secara parsial terhadap variabel dependen.

\section{Uji Koefisien determinasi}

Koefisien determinasi yang digunakan dalam penelitian ini adalah Adjusted Rsquared untuk mengukur seberapa besar proporsi variasi dari variable independen secara bersama-sama dalam mempengaruhi variable dependen. Hasil pengujian ini menunjukan seberapa besar variable independen dapat menjelaskan variable dependen.

\section{HASIL PENELITIAN DAN PEMBAHASAN}

Berdasarkan hasil analisis deskriptif statistic, maka data karekteristik sampel yang digunakan didalam penelitian ini meliputi : jumlah sampel $(\mathrm{N})$, rata-rata sampel (mean), nilai maksimum, nilai minimum serta standar deviasi $(\sigma)$ untuk masingmasing variabel.

Tabel 1

Hasil Uji Deskripsi Statistik

\begin{tabular}{|l|l|c|c|c|c|}
\hline Variabel & $\mathrm{N}$ & Minimum & Maksimum & Mean & Standar deviasi \\
\hline $\begin{array}{l}\text { X1 Komisaris) } \\
\text { Kewan }\end{array}$ & 30 & 4 & 8 & 6 & 1 \\
\hline X2 (Dewan Direksi) & 30 & 4 & 15 & 9 & 3 \\
\hline $\begin{array}{l}\text { X3 (Kepemilikan } \\
\text { institusional) }\end{array}$ & 30 & $1.27 \mathrm{E}+08$ & $3.57 \mathrm{E}+09$ & $1.10 \mathrm{E}+09$ & $9.45 \mathrm{E}+08$ \\
\hline Y(ROE) & 30 & 0.015000 & 0.424900 & 0.204317 & 0.206898 \\
\hline
\end{tabular}

Tabel 1 menggambarkan deskripsi statistik untuk masing-masing variabel yang digunakan jumlah data yang digunakan dalam penelitian ini adalah sebesar 30 data. Rata-rata jumlah dewan komisaris perusahaan sector keuangan adalah 6 . Rata-rata dewan direksi cukup besar yaitu sebesar 9. Rata-rata kepemilikan institusional yaitu 1.10E+09. dan rata-rata ROE adalah 0.204317. 
Tabel 2

Uji Stasioner

\begin{tabular}{|l|c|c|l|}
\hline \multirow{2}{*}{ Variabel } & \multicolumn{3}{|c|}{ Tingkat Stasioneritas } \\
\cline { 2 - 4 } & \multicolumn{3}{|c|}{ Differens } \\
\cline { 2 - 4 } & t-statistic & Probability & Keterangan \\
\hline X1 & -2.995485 & 0.0472 & Stasioner \\
\hline X2 & -4.523193 & 0.0013 & Stasioner \\
\hline X3 & -10.55146 & 0.0000 & Stasioner \\
\hline Y & -4.638828 & 0.0010 & Stasioner \\
\hline
\end{tabular}

Pada tabel 2 menunjukan hasil uji statistic ADF pada First Difference yang menunjukan bahwa hipotesis nol ditolak, dengan kata lain data pada dua variabel dan probabilitas setelah diturunkan satu kali data menjadi stasioner. Dengan ini A Absolut ADF lebih kecil dari nilai krisis pada tingkat keyakinan 0,05. Artinya semua variabel tersebut sudah tidak mengandung masalah akar unit dan mempunyai kondisidata stasioner pada tingkat atau derajat integrasi satu.

Tabel 3

Uji Multikolinearitas

\begin{tabular}{|l|c|c|c|}
\hline & X1 & X2 & X3 \\
\hline X1 & 1 & 0.775185245 & 0.195154960 \\
\hline X2 & 0.775185245 & 1 & 0.082657395 \\
\hline X3 & 0.195154960 & 0.0826573951 & 1 \\
\hline
\end{tabular}

Berdasarkan hasil olahan data pada table 3 terlihat nilai korelasi antara sesama variabel independen $<0,8$ sehingga dapat dikatakan bahwa sesama variabel independen tidak memiliki hubungan multikolinearitas.

Tabel 4

Uji Autokolerasi

\begin{tabular}{|l|c|}
\hline Model & Durbin Watson \\
\hline 1 & 0.792573 \\
\hline
\end{tabular}

Dari Uji Durbin-Watson pada tabel 4 terlihat bahwa tidak terjadi autokolrasi karena nilai DW antara $-2<0.792573<2$.

Tabel 5

Uji Heteroskedastisitas

\begin{tabular}{|l|l|l|l|}
\hline F-statistic & 2.958782 & Probability & 0.0517 \\
\hline Obs*R-squared & 7.598637 & Probability & 0.0551 \\
\hline
\end{tabular}

Pada tabel 5 terlihat tidak terjadi heteroskedastisitas karena nilai probability Obs*R-squared yaitu $0.0551>0,05$. 
Tabel 6

Uji Regresi Linier Berganda

\begin{tabular}{|c|c|c|c|c|}
\hline Variable & Coefficient & Std. Error & t-Statistic & Prob. \\
\hline $\bar{C}$ & -0.001357 & 0.064586 & -0.021012 & 0.9834 \\
\hline $\mathrm{X} 1$ & 0.002196 & 0.013690 & 0.160398 & 0.8739 \\
\hline $\mathrm{X} 2$ & 0.009943 & 0.005895 & 1.686842 & 0.1041 \\
\hline X3 & $3.21 \mathrm{E}-06$ & $9.38 \mathrm{E}-07$ & 3.423352 & 0.0021 \\
\hline
\end{tabular}

$\mathrm{Y}=-0.001357+0.002196 \mathrm{X} 1+0.009943 \mathrm{X} 2+3.32 \mathrm{E}-06 \mathrm{X} 3+\mathrm{e}$

. Dimana nilai konstanta sebesar -0.001357 artinya tanpa adanya dewan komisaris, dewan direksi, dan kepemilikan institusional maka nilai ROE akan turun sebesar -0.001357 .

\section{Uji f}

dihasilkan nilai $F$-statistic sebesar 8.274920 dengan nilai signifikan probability $F$-statistic adalah 0.000542 , tingkat probabilitasnya lebih kecil dari 0,05 atau < 0,05 . Hal tersebut mengidentifikasi bahwa semua variabel independen $(\mathrm{X} 1, \mathrm{X} 2$, dan X3) berpengaruh signifikan tehadap variabel dependen (ROE).

\section{Uji t}

Dari hasil pengolahan data dewan komisaris menunjukan $t_{\text {hitung }} 0.160398$ dengan nilai yang tidak signifikan 0.8739 lebih dari tingkat alpha 0,05 dan koefosien C sebesar 0.002196 menunjukan nilai positif. Hal ini berarti bahwa dewan komisaris berpengaruh positif tapi tidak signifikan terhadap kinerja keuangan yang di ukur dengan ROE. Untuk dewan direksi berpengaruh positif tapi tidak signifikan, dan kepemilikan institusional berpengaruh positif dan signifikan.

\section{PEMBAHASAN}

Dari tabel 4.9 dihasilkan nilai koefosien regresi untuk variabel dewan komisaris yang diproxy oleh (ROE) sebesar 0.002196 bertanda positif dengan probability $0,8739>0,05$ yang berarti bahwa dewan komisaris mempunyai pengaruh positif tapi tidak signifikan terhadap probabilitas yang diproxy oleh ROE. Dengan demikian dapat disimpulkan hipotesis pertama di tolak.

Dari hasil penelitian koefisien regresi dari dewan direksi sebesar 0,009943. Hal ini menunjukan dewan komisaris mempunyai pengaruh positif terhadap kinerja keuangan (ROE). Probabilitas menunjukan lebih besar dari 0,05 yaitu 0,1041 yang artinya bahwa variabel dewan direksi tidak signifikan terhadap kinerja keuangan (ROE). Dengan demikan dapat disimpulkan bahwa hipotesis kedua mengatakan dewan direksi memiliki pengaruh positif tapi tidak signifikan terhadap kinerja keuangan di tolak.

Dihasilkan dari nilai koefisien regresi untuk variabel kepemilikan institusional yang diproxy oleh ROE sebesar 3.21E+06 bertanda positif dengan niali probability $0.0021<0,05$ yang berarti bahwa kepemilikian institusional mempunyai pengaruh positif dan signifikan terhadap kinerja keuangan (ROE). Dengan demikian dapat disimpulkan hipotesis ketiga diterima. 


\section{SIMPULAN}

Berdasarkan hasil penelitian, dapat disimpulkan bahwa dewan komisaris, dewan direksi dan kepemilikan institusional dengan variabel control ukuran perusahaan secara bersama-sama berpengaruh secara signifikan terhadap variabel dependen yaitu ROE. Secara individual dewan komisaris tidak berpengaruh signifikan terhadap ROE. Semakin besar dewan komisaris maka tidak mempengaruhi jumlah ROE yang dihasilkan.

Sama dengan dewan komisaris, dewan direksi berpengaruh positif tapi tidak signifikan terhadap ROE. Artinya semakin besar dewan komisaris akan berpengaruh pada jumlah ROE yang dihasilkan.

Kepemilikan institusional juga mempunyai pengaruh terhadap kinerja keuangan. Hasil ini menjukan bahwa kepemilikan saham oleh institusi diluar perusahaan mampu menjadi kontroler dalam pengambilan keputusan oleh manajemen sehingga tercipta kinerja keuangan yang baik.

\section{DAFTAR PUSTAKA}

Agustina, Melia. 2013. "Pengaruh Good Corporate Governance Terhadap Kinerja Keuangan Perusahaan pada Sektor Keuangan". Akutansi Bisnis Universitas Kristen Petra.

Al-Amameh, A. (2014). Corporate Governance, Ownership Stucture and Bank Performance in Jordan. International Journal of Economics and Finance, 6(6), 69-81.

Arifin, I. Z., \& Marlius, D. (2017). Analisis Kinerja Keuangan PT. Pegadaian Cabang Ulak Karang. https://doi.org/10.31227/osf.io/n2peu

Attar, d., Islahuddin, \& Shabri, M. (2014). Pengaruh Penerapan Manajemen Risiko terhadap Kinerja Keuangan Perbankan yang Terdaftar di Bursa Efek Indonesia. Jurnal Akuntansi, 3(1), 10-20.

Darmawati, Deni., Khomsiyah., dan Rahayu, Rika Gelar. 2004. Hubungan Corporate Governance dan Kinerja Perusahaan. Simposium Nasional Akuntansi VII. Denpasar.

FCGI. (n.d.). Peranan Dewan Komisaris dan Komite Audit dalam Pelaksanaan Corporate Governance (tata Kelola Perusahaan) Jilid 2.

Ghozali, imam. 2005. Aplikasi Analisis Multivariate dengan program SPSS. Semarang: Badan Penerbit Universitas Diponegoro.

Mayliza, R. (2019). Pengaruh Good Corporate Governance Dan Leverage Terhadap Kinerja Keuangan Pada Perbankan Yang Terdaftar Di BEI. https://doi.org/10.17605/OSF.IO/M9DT6 
Muh. Arief effendi. 2009. The Power of Good Corporate Governance: Teori dan Implementasi. Jakarta: Salemba Empat.

OECD. (2004). The OECD Principles of Corporate Governance. France: Organization for Economic Co-operation and development (OECD) Publication service.

Permatasari, I., \& Novitasari, I. (2014). Pengaruh Implementasi Good Corporate Governance terhadap Permodalan dan Kinerja Perbankan di Indonesia: Manajemen Risiko sebagai Variabel Intervening. JurnalEkonomi Kuantitatif Terapan, 7(1), 52-59.

Rahmayeli, D. S., \& Marlius, D. (2017). Analisis Kinerja Keuangan Pada PT. Bank Perkreditan Rakyat (BPR) Batang Kapas Pesisir Selatan. https://doi.org/10.31227/osf.io/sz5db

Salman, A. K., \& Yazdanfar. D.(2012). Profitabiliti in Swedish Micro Firms: a quantile Regression Approach. International Business Research, 5(8), 94106.

Sam'ani. 2008. “ Pengaruh Good Corporate Governance dan Leverage Terhadap Kinerja Keuangan Pada Perusahaan yang Terdaftar Di Bursa Efek Indonesia (BEI) Tahun 2004-2007'. Tesis S2. Semarang: Fakultas Ekonomi, Universitas Diponegoro.

Santoso, Agus. 2000. Ringkasan Teori Manajemen Keuangan Soal dan Penyelesaiannya (edisi 3). Yogyakarta: BPFE.

Susanti, Emillia. 2013. “Pengeruh pelaksaan Good Corporate Governance, Kepemilikan Institusional dan Leverage Terhadap Kinerja Keuangan”. Skripsi. Padang: Fakultas Ekonomi, Universitas Negri Padang.

Tarjo. 2008. "Pengaruh Konsentrasi Kepemilikan Insstitusional dan Leverage Terhadap Manajemen Laba, Nilai Pemegang Saham Serta Cost of Equity Capital”. Simposium Nasional Akuntansi XI, Pontianak.

Yi Lin, H. (2010). The Agency Problem in Taiwan's Corporate Governance. The Journal of International Management Studies, 5(1), 11-22. 